\title{
Design, Synthesis and Docking Studies of Novel 1, 2, 3-Triazolyl Phenylthiazole Analogs as Potent Anti-HIV-1 NNRT Inhibitors
}

Hanmant M Kasralikar ${ }^{1}$, Suresh C Jadhavar ${ }^{1}$, Sujit G Bhansali ${ }^{2}$, Shivaji B Patwari ${ }^{3}$ and Sudhakar R Bhusare ${ }^{{ }^{\star}}$

${ }^{1}$ Department of Chemistry, Dnyanopasak College, Parbhani, Maharashtra, India

${ }^{2}$ Poona College of Pharmacy, Bharati Vidyapeeth Deemed University, Pune, Maharashtra, India

${ }^{3}$ Department of Chemistry, LBS Mahavidyalaya, Dharmabad, Nanded District, Maharashtra, India

\begin{abstract}
In an attempt to design and synthesize a new class of anti-HIV-1 RTIs i.e., 4-(phenyl)-N,N-bis((1-phenyl$1 \mathrm{H}-1,2,3$-triazol-4-yl)methyl)thiazol-2-amine derivatives, substituted 2-amino-4-phenylthiazoles were alkylated with propargyl bromide to obtain dialkyne 2-amino-4-phenylthiazoles. This dialkyne 2-amino-4-phenylthiazole was reacted with aryl azides to generate small library of 15 compounds (4a-o) by click chemistry. The obtained derivatives were studied for as an anti-HIV-1 NNRT Inhibitors. All synthesized compounds of 1,2,3-triazolylphenylthiazole series were be docked into the non-nucleoside inhibitor binding pocket (NNIBP) of HIV-1 RT and highly inhibiting derivatives studied for in vitro anti-HIV-1 assay.
\end{abstract}

Keywords: 4-(Phenyl)-N, N-bis((1-phenyl-1H-1,2,3-triazol-4-yl) methyl)thiazol-2-amine; Dialkyne 2 amino-4-phenylthiazole; AntiHIV-1 NNRTI

\section{Introduction}

Reverse transcriptase inhibitors (RTIs) are a class of antiretroviral drugs used to treat HIV infection or AIDS, and in some cases hepatitis B. RTIs inhibit activity of reverse transcriptase, a viral DNA polymerase that is required for replication of HIV and other retroviruses. When HIV infects a cell, reverse transcriptase copies the viral single stranded RNA genome into a double stranded viral DNA. The viral DNA is then integrated into the host chromosomal DNA, which then allows host cellular processes, such as transcription and translation to reproduce the virus. RTIs block reverse transcriptase's enzymatic function and prevent completion of synthesis of the double stranded viral DNA, thus preventing HIV from multiplying.

A similar process occurs with other types of viruses. The hepatitis B virus, for example, carries its genetic material in the form of DNA, and employs a RNA dependent DNA polymerase to replicate. Some of the same compounds used as RTIs can also block HBV replication; When used in this way they are referred to as polymerase inhibitors. HIV only contains RNA and so needs to change its RNA into DNA to be able to integrate with our DNA for replication. To do this it has to first change its RNA to DNA. HIV uses a compound called reverse transcriptase to convert its RNA to DNA. Reverse transcriptase enzyme is not found in human cell without HIV, so that RT is the main target for the Anti-HIV drug synthesis.

RTIs come in three forms: Nucleoside analog reverse transcriptase inhibitors (NARTIs or NRTIs) Nucleotide analog reverse transcriptase inhibitors (NtARTIs or NtRTIs) and Nonnucleoside Reverse transcriptase inhibitors (NNRTIs). The mode of action of NRTIs and NtRTIs is essentially the same; They are analogues of the naturally occurring deoxynucleotides needed to synthesize the viral DNA and they compete with the natural deoxynucleotides for incorporation into the growing viral DNA chain. NRTI working different ways but one of the main ways is to compete with reverse transcriptase for their interaction site with HIV genetic material while NNRTIs work by sitting in a binding site in the virus structure.

Non-nucleoside reverse transcriptase inhibitors (NNRTIs) are the third class of antiretroviral drugs that were developed. In all cases, patents remain in force until beyond 2007.
The 2-amino-1,3-thiazoles are biologically important compounds with a wide range of medicinal and biological applications including antibacterial, antifungal, anti-HIV, anti-hypertension, antiinflammatory, anticancer, anticonvulsant, and antidepressant [1-6]. Some 2-amino-1,3-thiazole derivatives have been reported as ligands of thrombopoietin [7,8], neuropeptide Y5 [9] and adenosine receptors $[10,11]$ and as inhibitors of several physiological important enzymes like cyclindependant kinase [12], poly (ADP-Ribose) polymerase [13], urokinase [14] etc. Thiazole is also considered as a heterocyclic bioisostere of the phenol moiety in the extensively used antiparkinsonian agent pramipexol [15] and in morphinan derivatives $[16,17]$. Due to their broad utility in the pharmaceutical industry, the development of methods that give quick access to diverse 2-amino1,3-thiazole libraries would provide additional lead molecules for drug discovery.

However, 1,2,3-triazole ring is not found in any marketed drugs. The click chemistry improved by Sharpless et al. is an admirable approach for regioselective synthesis of 1,2,3-triazole ring system in presence of various functional groups. Genuine efforts have been made to integrate 1, 2, 3-triazole in existing drugs, still more research is needed to find lead molecule [18]. 1,2,3-triazole structural moiety is present in several compounds showing various biological activities including anti-HIV [19], anti-bacterial [20], anti-allergic [21], anticonvulsant [22], b-llactamase inhibitory [23], and anti-tuberculosis activities [24], 1,2,3-triazole has been comprehensively studied due to its important applications in industrially interesting materials, such as dyes, anticorrosive agents, photo stabilizers, photographic materials, and agrochemicals [18]. Therefore, we found it interesting to design new molecules within the scope of synthetic procedure using

*Corresponding author: Sudhakar $\mathrm{R}$ Bhusare, Department of Chemistry Dnyanopasak College, Parbhani-431 401, Maharashtra, India, Tel: 9440396666 E-mail: bhusare71@yahoo.com

Received September 27, 2016; Accepted October 03, 2017; Published October 10, 2017

Citation: Kasralikar HM, Jadhavar SC, Bhansali SG, Patwari SB, Bhusare SR (2017) Design, Synthesis and Docking Studies of Novel 1, 2, 3-Triazoly Phenylthiazole Analogs as Potent Anti-HIV-1 NNRT Inhibitors. Med Chem (Los Angeles) 7: 268-275. doi: 10.4172/2161-0444.1000467

Copyright: @ 2017 Kasralikar HM, et al. This is an open-access article distributed under the terms of the Creative Commons Attribution License, which permits unrestricted use, distribution, and reproduction in any medium, provided the original author and source are credited. 
Citation: Kasralikar HM, Jadhavar SC, Bhansali SG, Patwari SB, Bhusare SR (2017) Design, Synthesis and Docking Studies of Novel 1, 2, 3-Triazolyl Phenylthiazole Analogs as Potent Anti-HIV-1 NNRT Inhibitors. Med Chem (Los Angeles) 7: 268-275. doi: 10.4172/2161-0444.1000467

phenylthiazole scaffold followed by suitable modification to generate diversified compounds for anti-HIV activity. In this study, we exploited click chemistry for synthesis of diversified phenylthiazole compounds mainly for the two reasons; first, it can tolerate wide range of functional groups and easy to do eco-friendly reactions at room temperature either in water or mixture of water and organic solvents, secondly; this approach will generate compounds having 1,2,3-triazole functionality rather than 1,2,4-triazole. These compounds can be studied for antiHIV-1 RT activities.

The study of new hybrid systems in which 1,2,3-triazole and 2-amino-4-phenyl-1,3-thiazole are combined comprises an unfamiliar field of research. These findings have encouraged us to investigate the potential synergistic effect of 1,2,3-triazole and 2-amino-4phenyl-1,3-thiazole scaffolds. Herein, for the first time, we report the hybridization of these two pharmacophores and their anti-HIV-1 NNRTI ability. It has been hope that combination of these active groups in the new molecular design would lead to better anti-HIV-1 agents. In this communication, we report the synthesis of newly designed 4-(phenyl)-N, N-bis ((1-phenyl-1H-1,2,3-triazol-4-yl)methyl)thiazol2-amine derivatives starting from dialkyne substituted 2-amino-4phenylthiazole derivatives which has been synthesized from substituted 2-amino-4-phenyl-1,3-thiazole and propargyl bromide.

\section{Experimental}

All solvents were used as commercial anhydrous grade without further purification. Aluminium sheets $20 \times 20 \mathrm{~cm}$, Silica gel $60 \mathrm{~F}_{254}$, Merck grade was used for thin layer chromatography to determine progress of reaction. Melting points were determined in open capillary tube and are uncorrected ${ }^{1} \mathrm{H}$ NMR spectral data were recorded on Brucker Advance spectrometer at $300 \mathrm{MHz}$ and Jeol JNM ECX spectrometer at $300 \mathrm{MHz}$ using TMS as an internal standard. The chemical shifts values are recorded on $\delta$-scale in DMSO solvent. Mass spectra were taken on Polaris-Q Thermo scientific GC-MS.

General procedure for synthesis of dialkyne substituted 2-amino-4-phenylthiazoles derivatives $(2 \mathrm{a}, 2 \mathrm{~b})$

A mixture of aniline $(0.5 \mathrm{mmol})$, allyl bromide $(1.5 \mathrm{mmol})$, potassium carbonate $(2 \mathrm{mmol})$, ethanol $(2 \mathrm{~mL})$, and water $(1 \mathrm{~mL})$ was added to a $50 \mathrm{~mL}$ round flask ask and stirred at $70^{\circ} \mathrm{C}$ for the desired time until complete consumption of starting material as judged by TLC. Then, the reaction mixture was condensed by evaporation of solvents under reduced pressure and was washed with saturated sodium carbonate solution and poured into a separating funnel [25].

The content was extracted with ethyl acetate $(10 \mathrm{~mL} \times 3)$, and the combined organic layers were dried over anhydrous magnesium sulfate. The solvent was removed by evaporation under reduced pressure to afford the two products ( $2 \mathrm{a}$ and $2 \mathrm{a}_{1}$ i.e., monoalkyne substituted 2-amino-4-phenylthiazole), which were purified by column chromatography using hexane and dichloromethane (65:35) as eluent. The major product was compound $\mathbf{2 a}$, which was used for synthesis of next step compounds (4a-o) which were further purified by column chromatography on silica gel using petroleum ether and ethyl acetate as the eluents.

4-(4-methoxyphenyl)-N,N-di(prop-2-ynyl) thiazol-2-amine (2a): Yellow solid; M.P. $\left(196^{\circ} \mathrm{C}\right):{ }^{1} \mathrm{H}$ NMR (300 MHz, DMSO): $\delta 2.35$ $(\mathrm{t}, 2 \mathrm{H}), 3.82(\mathrm{~s}, 3 \mathrm{H}), 4.76(\mathrm{~d}, 4 \mathrm{H}), 7.77(\mathrm{~s}, 1 \mathrm{H}), 7.86(\mathrm{~d}, 2 \mathrm{H}), 7.96(\mathrm{~d}, 2 \mathrm{H})$ ; ${ }^{13} \mathrm{C}-\mathrm{NMR}\left(300 \mathrm{MHz}, \mathrm{CDCl}_{3}\right.$ ): $\delta 167.02,152.26,148.06,131.41,126.11$, 114.01, 110.82, 77.44, 73.42, 56.26, 39.22; GC-MS: $m / z 282.08\left(\mathrm{M}^{+}\right)$;
Elemental Analysis: $\mathrm{C}_{16} \mathrm{H}_{14} \mathrm{~N}_{2} \mathrm{OS}$ : C, 68.08; H, 5.00; N, 9.92; Found C, $68.05 ; \mathrm{H}, 4.98 ; \mathrm{N}, 9.90$

4-(4-chlorophenyl)-N,N-di(prop-2-ynyl) thiazol-2-amine (2b): Yellow solid; M.P. $\left(180^{\circ} \mathrm{C}\right):{ }^{1} \mathrm{H}$ NMR $\left(300 \mathrm{MHz}, \mathrm{CDCl}_{3}\right): \delta 2.31(\mathrm{t}$, $2 \mathrm{H}), 4.46(\mathrm{~d}, 4 \mathrm{H}), 7.14(\mathrm{~s}, 1 \mathrm{H}), 7.32(\mathrm{~m}, 2 \mathrm{H}), 7.64(\mathrm{~m}, 2 \mathrm{H}) ;{ }^{13} \mathrm{C}-\mathrm{NMR}$ $\left(300 \mathrm{MHz}, \mathrm{CDCl}_{3}\right): \delta 153.20,149.00,136.21,131.40,126.21,115.80$, 111.82, 78.44, 73.72, 40.22; GC-MS: $m / z 286.03\left(\mathrm{M}^{+}\right)$; Elemental Analysis: $\mathrm{C}_{15} \mathrm{H}_{11} \mathrm{Cl} \mathrm{N}$ S: C, 62.82; $\mathrm{H}, 3.87 ; \mathrm{N}, 9.77$; Found C, 62.80; H, 3.84; $\mathrm{Cl}, 12.33, \mathrm{~N}, 9.73$.

General procedure for the synthesis of 4-(phenyl)-N, N-bis ((1-phenyl-1H-1, 2, 3-triazol-4-yl) methyl) thiazol-2-amine derivatives (4a-o)

The synthesis of various azides was carried out according to the literature procedure [26]. Briefly, aniline (1 eq, $5 \mathrm{mmol}$ ) was dissolved in $6 \mathrm{~N} \mathrm{HCl}$ solution $(20 \mathrm{ml})$ at room temperature and cooled up to $0^{\circ} \mathrm{C}$, followed by addition of a solution of $\mathrm{NaNO}_{2}$ ( 1 eq, $5 \mathrm{mmol}$ ). The reaction mixture was stirred for $10 \mathrm{~min}$ at $0-5^{\circ} \mathrm{C}$. Sodium azide (1.2 eq, $6 \mathrm{mmol}$ ) was added and mixture was further stirred at room temperature for $2 \mathrm{~h}$. The reaction was worked up by dilution with ethyl acetate. The organic layer was washed with brine solution and dried over sodium sulfate. After evaporation of the solvent, the crude product 2 (a-t) was pure enough for further reactions. To this add dialkyne substituted 2-amino-4-phenylthiazole (2a, b) $(1 \mathrm{mmol})$ suspended in $\mathrm{N}, \mathrm{N}$ '-dimethylformamide $(10 \mathrm{ml})$. Sodium ascorbate $(0.3 \mathrm{mmol}$, in water) was added, followed by copper (II) sulfatepentahydrate $(0.03$ $\mathrm{mmol}$, in water). The heterogeneous mixture was stirred vigorously over $24-48 \mathrm{hrs}$, and the completion of reaction was monitored by TLC. After completion of the reaction, the reaction mixture was diluted with water, cooled in ice, and the precipitate was collected by filtration [27].

N,N-bis((1-(2-chlorophenyl)-1H-1,2,3-triazol-4-yl)methyl)4-(4-methoxyphenyl)thiazol-2-amine (4b): White solid; M.P. (135 ${ }^{\circ} \mathrm{C}$ ): ${ }^{1} \mathrm{H}$ NMR (300 MHz, DMSO): $\delta 3.66$ (s, 3H), 5.12 (s, 2H),7.12 (s, $1 \mathrm{H}), 7.30(\mathrm{t}, 1 \mathrm{H}), 7.42(\mathrm{t}, 2 \mathrm{H}), 7.53(\mathrm{t}, 2 \mathrm{H}), 7.80(\mathrm{t}, 2 \mathrm{H}), 8.51(\mathrm{~s}, 1 \mathrm{H})$; ${ }^{13} \mathrm{C}-\mathrm{NMR}$ (300MHz, DMSO): $\delta 167.45,162.77,155.03,152.59,143.58$ $131.26,131.26,131.24,126.23,126.03,124.32,121.66,119.24,115.33$, 112.41, 105.33, 55.68, 45.92; GC-MS: $m / z 589.5\left(\mathrm{M}^{+}\right)$; Elemental Analysis: $\mathrm{C}_{28} \mathrm{H}_{22} \mathrm{Cl}_{2} \mathrm{~N}_{8} \mathrm{OS}$ : C, 57.05; H, 3.76; N, 19.07; Found C, 57.05; $\mathrm{H}, 3.76$;, 19.07 .

N,N-bis((1-(2-fluorophenyl)-1H-1,2,3-triazol-4-yl)methyl)-4(4-methoxyphenyl)thiazol-2-amine (4g): White solid; M.P. $\left(122^{\circ} \mathrm{C}\right)$ : ${ }^{1} \mathrm{H}$ NMR (300 MHz, DMSO): $\delta 3.75$ (s, 3H), 5.02 (s, 2H), 7.12 (s, $1 \mathrm{H}), 7.30(\mathrm{t}, 1 \mathrm{H}), 7.40(\mathrm{t}, 2 \mathrm{H}), 7.57(\mathrm{t}, 2 \mathrm{H}), 7.80(\mathrm{t}, 2 \mathrm{H}), 8.60(\mathrm{~s}, 1 \mathrm{H})$ ${ }^{13} \mathrm{C}-\mathrm{NMR}(300 \mathrm{MHz}, \mathrm{DMSO}): \delta 167.45,161.26,155.05,152.58,143.70$, $131.32,131.13,126.29,126.19,124.40,120.81,119.23,115.59,112.64$ 105.09, 55.33, 45.92; GC-MS: $m / z 556.16\left(\mathrm{M}^{+}\right)$; Elemental Analysis: $\mathrm{C}_{28} \mathrm{H}_{22} \mathrm{~F}_{2} \mathrm{~N}_{8} \mathrm{OS}$ : C, 60.42; H, 3.98; N, 20.13; Found C,60.40; H, 3.95; N, 20.09 .

4-(4-methoxyphenyl)-N,N-bis((1-(3,4-dimethylphenyl)-1H1,2,3-triazol-4yl)methyl) thiazol-2-amine (4h): White solid; M.P. $\left(176^{\circ} \mathrm{C}\right),{ }^{1} \mathrm{H}$ NMR $(300 \mathrm{MHz}, \mathrm{DMSO}): \delta 2.13(\mathrm{~m}, 6 \mathrm{H}), 3.65(\mathrm{~s}, 3 \mathrm{H}), 4.99$ (s, 2H), $7.08(\mathrm{t}, 1 \mathrm{H}), 7.31(\mathrm{~d}, 2 \mathrm{H}), 7.54(\mathrm{q}, 2 \mathrm{H}), 7.77(\mathrm{~d}, 1 \mathrm{H}), 8.72(\mathrm{~s}, 1 \mathrm{H})$; ${ }^{13} \mathrm{C}-\mathrm{NMR}(300 \mathrm{MHz}, \mathrm{DMSO}): \delta 161.70,157.51,152.51,145.22,134.72$ $131.24,129.01,126.41,125.98,121.59,119.18,100.58,56.41,42.95$, 28.42; GC-MS: $m / z$ 576.24 $\left(\mathrm{M}^{+}\right)$; Elemental Analysis: $\mathrm{C}_{32} \mathrm{H}_{32} \mathrm{~N}_{8} \mathrm{OS}$ : C,66.64; H, 5.59; N,19.43; Found C, 66.60; H, 5.55; N,19.39.

4-(4-chlorophenyl)-N,N-bis((1-(2-chlorophenyl)-1H-1,2,3triazol-4-yl)methyl)thiazol-2-amine (4i): White solid; M.P. $\left(142^{\circ} \mathrm{C}\right)$ : 
${ }^{1} \mathrm{H}$ NMR (300 MHz, DMSO): $\delta 5.07(\mathrm{~s}, 2 \mathrm{H}), 7.12(\mathrm{~s}, 1 \mathrm{H}), 7.30(\mathrm{t}, 1 \mathrm{H})$, $7.42(\mathrm{t}, 2 \mathrm{H}), 7.53(\mathrm{t}, 2 \mathrm{H}), 7.85(\mathrm{t}, 2 \mathrm{H}), 8.64(\mathrm{~s}, 1 \mathrm{H}) ;{ }^{13} \mathrm{C}-\mathrm{NMR}(300 \mathrm{MHz}$, DMSO): $\delta 165.55,155.12,152.12,143.74,136.26,134.32,132.59$, $131.13,126.29,126.19,124.40,120.84,116.63,116.42,104.59,42.98$; GC-MS: $m / z 592.05\left(\mathrm{M}^{+}\right)$; Elemental Analysis: $\mathrm{C}_{27} \mathrm{H}_{19} \mathrm{Cl}_{3} \mathrm{~N}_{8} \mathrm{~S}: ; \mathrm{C}, 54.60$; H, 3.22; N, 18.87; Found C, 54.57; H, 3.20; N, 18.85 .

4-(4-chlorophenyl)-N,N-bis((1-(2-fluorophenyl)-1H-1,2,3triazol-4-yl)methyl)thiazol-2-amine $(4 \mathrm{n})$ : White solid; M.P. $\left(126^{\circ} \mathrm{C}\right)$ : ${ }^{1} \mathrm{H}$ NMR (300 MHz, DMSO): $\delta 5.02(\mathrm{~s}, 3 \mathrm{H}), 7.12(\mathrm{~s}, 1 \mathrm{H}), 7.31(\mathrm{t}, 1 \mathrm{H})$, $7.43(\mathrm{t}, 2 \mathrm{H}), 7.63(\mathrm{t}, 2 \mathrm{H}), 7.81(\mathrm{t}, 2 \mathrm{H}), 8.59(\mathrm{~s}, 1 \mathrm{H}) ;{ }^{13} \mathrm{C}-\mathrm{NMR}(300 \mathrm{MHz}$ DMSO): $\delta 165.51,155.11,152.64,143.74,136.26,134.32,132.59$, 131.19, 126.19, 124.43, 120.83, 116.66, 116.40, 104.66, 42.93; GC-MS: $\mathrm{m} / z 560.11\left(\mathrm{M}^{+}\right)$; Elemental Analysis: $\mathrm{C}_{27} \mathrm{H}_{19} \mathrm{ClF}_{2} \mathrm{~N}_{4} \mathrm{~S}: \mathrm{C}, 57.80 ; \mathrm{H}, 3.41$; $\mathrm{N}, 19.97$; Found C, 57.80; H, 3.41; N, 19.97 .

4-(4-chlorophenyl)-N,N-bis((1-(3,4-dimethylphenyl)-1H-1,2,3triazol-4-yl)methyl)thiazol-2-amine (4o): White solid; M.P. $\left(195^{\circ} \mathrm{C}\right)$ : ${ }^{1} \mathrm{H}$ NMR (300 MHz, DMSO): $\delta 2.14(\mathrm{~m}, 6 \mathrm{H}), 4.98(\mathrm{~s}, 2 \mathrm{H}), 7.10(\mathrm{~s}, 1 \mathrm{H})$, $7.32(\mathrm{~d}, 2 \mathrm{H}), 7.54(\mathrm{~d}, 2 \mathrm{H}), 7.79(\mathrm{~d}, 2 \mathrm{H}), 8.70(\mathrm{~s}, 1 \mathrm{H}) ;{ }^{13} \mathrm{C}-\mathrm{NMR}(300 \mathrm{MHz}$, DMSO): $\delta 163.15,152.71,143.58,139.64,136.63,132.68,131.42$, $130.40,129.24,126.20,124.32,123.49,121.33,119.24,100.34,30.92$, 21.23; GC-MS: $m / z 580.19\left(\mathrm{M}^{+}\right)$; Elemental Analysis: $\mathrm{C}_{31} \mathrm{H}_{29} \mathrm{Cl} \mathrm{N}_{8} \mathrm{~S}: \mathrm{C}$, 64.07; H, 5.03; N, 19.28; Found C, 64.05; H, 5.01; N, 19.25.

\section{Material and methods for docking studies}

To guide the lead optimization strategy and rationalize the SARs, modeling study was performed to examine the possible binding conformations of our newly synthesized compounds and their interaction mode with RT, using Glide (Glide 5.8, Schrodinger, 2012) [28]. Structure-based docking studies were carried out to investigate the intermolecular interaction between the ligand and the targeted enzyme. The coordinates of the non-nucleoside binding site were taken from the crystal structure of HIV-1 reverse transcriptase (RT) in complex with TMC278 (Rilpivirine) (PDB code: 2ZD1) [29]. Docking study of all the molecules from Indolyl and chromenyl xanthenone series was carried out with enzyme reverse transcriptase PDB ID: 2ZD1. The ligands were prepared by using LigPrep (LigPrep 2.5, Schrodinger, 2012) [30]. The protein was refined using the protein preparation wizard present in Maestro 9.3 (Maestro 9.3, Schrodinger, 2012) [31]. All the water molecules were deleted. $\mathrm{H}$ atoms were added to the protein, including the protons necessary to define the correct ionization and tautomeric states of the amino acid residues. Prime interface module incorporated in Maestro was used to add the missing residues of the side chain. Each structure minimization was carried out with the impact refinement module, using the OPLS-2005 force field to alleviate steric clashes potentially existing in the structures. Minimization was terminated when the energy converged or the root mean square deviation reached a maximum cutoff of $0.30 \AA$. To find out active site grid was prepared using grid generation panel of glide with the default settings. Grid is prepared for defining the binding site of native ligand on the receptor. The ligand was selected to define the position and size of the active site (Friesner et al.; Halgren et al.) [32,33]. Glide XP docking was used for docking purposes.

\section{Results and Discussion}

\section{Chemistry}

Various 4-(phenyl)-N,N-bis((1-phenyl 1H-1, 2, 3-triazol-4-yl) methyl)thiazol-2-amine derivatives were generated by reacting 2-amino-4-phenylthiazole with propargyl bromide in presence of base $\mathrm{K}_{2} \mathrm{CO}_{3}$ in dry acetone which yielded $2 \mathrm{a}$ (major) and $2 \mathrm{a}_{1}$ (minor). The compound 2 a containing propargyl group at 2-position was used as substrate to further generate small 1,4-disubstituted 1,2,3-triazole library of 15 compounds (4a-o) by reacting various substituted aromatic azides using click chemistry as outlined in Scheme 1. The detailed general synthesis procedure of the compounds is mentioned in the experimental section. Exploration of the substrate scope for the synthesis of 4 -(phenyl)-N, N-bis ((1-phenyl $1 \mathrm{H}-1,2,3$-triazol-

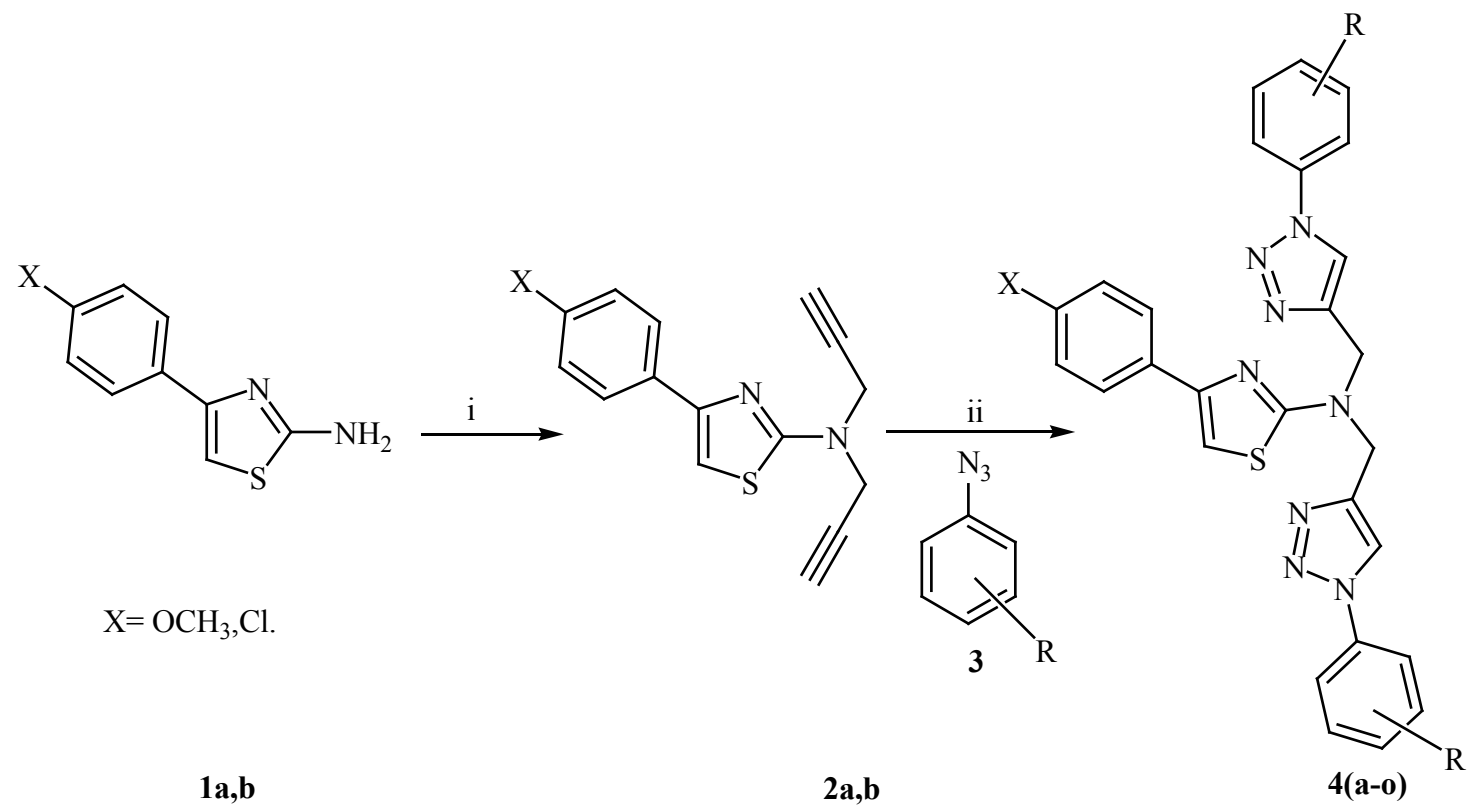

Scheme 1: Reagent and Conditions: i) $\mathrm{K}_{2} \mathrm{CO}_{3}, \mathrm{KI}$, Dry acetone, Propargyl bromide, reflux, $16 \mathrm{hrs}$. ii) $\mathrm{CuSO}_{4} \cdot 5 \mathrm{H}_{2} \mathrm{O}, \mathrm{Sodium}$ ascorbate, DMF: $\mathrm{H}_{2} \mathrm{O}$ (2:1), Stirr 24-48 hrs, RT, 61-78\%. 
4-yl)methyl)thiazol-2-amine derivatives is as shown in Table 1. All synthesized compounds (4a-o) were characterized by GC-MS, ${ }^{1} \mathrm{H}$ and ${ }^{13} \mathrm{C}$ NMR. The conversion of the acetylene group of $2 \mathrm{a}, \mathrm{b}$ into the triazole ring of the product $4 \mathrm{a}-\mathrm{o}$ can be confirmed by melting points and ${ }^{1} \mathrm{H}$ and ${ }^{13} \mathrm{C}$ NMR. A difference in the melting point, the high solubilities of 2a,b in $\mathrm{CDCl}_{3}$ and in DMSO, while the product 4a-o is soluble only in DMSO, the ${ }^{1} \mathrm{H}$ NMR spectra of $4 \mathrm{a}-\mathrm{o}$, the $\mathrm{NH}_{2}$ protons of 2-amino-4-phenylthiazole moiety disappeared by alkylation using propargyl bromide. In ${ }^{1} \mathrm{H}-\mathrm{NMR}$ of compound 2 a,b the protons attached to $\mathrm{N}-\underline{\mathrm{CH}}_{2}$ and acetylene proton occurred at $\delta 3.82-4.46$ and 2.31-2.35 respectively. The carbons attached to $\mathrm{N}-\mathrm{CH}_{2}$ and acetylene occurred at 40.22-39.22 and 73.42-73.72, 77.44-78.44 respectively. Mass spectra of 2a,b were corresponding to their molecular weight. In addition, of aromatic azides to $2 \mathrm{a}$ and $2 \mathrm{~b}$, some direct $\mathrm{C}-\mathrm{H}$ correlations were observed, confirming that the signals of the triazolyl chain $\mathrm{N}-\mathrm{C}=\mathrm{C}$ carbons appeared at $\delta 145.22-143.20 \mathrm{ppm}$. The appearance of C-H peak of triazolyl ring in $4 \mathrm{a}-\mathrm{o}$ at $\delta 8.70-8.51 \mathrm{ppm}$ shows the formation of the final Products. The presence of a molecular ion peak at respective $\mathrm{m} / \mathrm{z}$ value of all the products in the GC-MS further confirmed the structure of $4 \mathrm{a}-\mathrm{o}$. For all the spectra of compounds, please refer to the Supporting information

\begin{tabular}{|c|c|c|c|c|c|}
\hline Entry & $\mathbf{X}$ & Substituted Aldehyde (R) & Product & MP $^{\circ} \mathbf{C}$ & Yield $^{\mathbf{~ \%}}$ \\
\hline $\mathbf{1}$ & $-\mathrm{OCH}_{3}$ & $\mathrm{H}$ & $4 \mathrm{a}$ & $130-132$ & 65 \\
\hline $\mathbf{2}$ & $-\mathrm{OCH}_{3}$ & $2-\mathrm{Cl}$ & $4 \mathrm{~b}$ & $135-137$ & 68 \\
\hline $\mathbf{3}$ & $-\mathrm{OCH}_{3}$ & $4-\mathrm{Cl}$ & $4 \mathrm{c}$ & $187-189$ & 72 \\
\hline $\mathbf{4}$ & $-\mathrm{OCH}_{3}$ & $4-\mathrm{Br}$ & $4 \mathrm{~d}$ & $165-167$ & 74 \\
\hline $\mathbf{5}$ & $-\mathrm{OCH}_{3}$ & $3-\mathrm{NO}_{2}$ & $4 \mathrm{e}$ & $150-152$ & 78 \\
\hline $\mathbf{6}$ & $-\mathrm{OCH}_{3}$ & $4-\mathrm{NO}_{2}$ & $4 \mathrm{f}$ & $146-148$ & 64 \\
\hline $\mathbf{7}$ & $-\mathrm{OCH}_{3}$ & $2-\mathrm{F}$ & $4 \mathrm{~g}$ & $122-124$ & 63 \\
\hline $\mathbf{8}$ & $-\mathrm{OCH}_{3}$ & $3,4-\mathrm{CH}_{3}$ & $4 \mathrm{~h}$ & $176-178$ & 69 \\
\hline $\mathbf{9}$ & $-\mathrm{Cl}$ & $2-\mathrm{Cl}_{2}$ & $4 \mathrm{i}$ & $142-144$ & 74 \\
\hline $\mathbf{1 0}$ & $-\mathrm{Cl}$ & $4-\mathrm{Cl}$ & $4 \mathrm{j}$ & $174-176$ & 64 \\
\hline $\mathbf{1 1}$ & $-\mathrm{Cl}$ & $4-\mathrm{Br}$ & $4 \mathrm{k}$ & $148-150$ & 62 \\
\hline $\mathbf{1 2}$ & $-\mathrm{Cl}$ & $3-\mathrm{NO}_{2}$ & $4 \mathrm{l}$ & $156-158$ & 78 \\
\hline $\mathbf{1 3}$ & $-\mathrm{Cl}$ & $4-\mathrm{NO}_{2}$ & $4 \mathrm{~m}$ & $163-165$ & 72 \\
\hline $\mathbf{1 4}$ & $-\mathrm{Cl}$ & $2-\mathrm{F}$ & $4 \mathrm{n}$ & $126-128$ & 61 \\
\hline $\mathbf{1 5}$ & $-\mathrm{Cl}$ & $3,4-\mathrm{CH}_{3}$ & $4 \mathrm{o}$ & $195-197$ & 65 \\
\hline
\end{tabular}

alsolated yields

Table 1: Exploration of the substrate scope for the synthesis of 4-(phenyl)-N, N-bis ((1-phenyl 1H-1, 2, 3-triazol-4-yl)methyl)thiazol-2-amine derivatives.

\section{Molecular docking}

Docking score of compound $\mathbf{4 k}$ and $\mathbf{4 h}$ was found to be good around -11.126 and -11.125 respectively (Table 2 ). All molecules from 4-(phenyl)-N,N-bis((1-phenyl-1H-1,2,3-triazol-4-yl)methyl)thiazol-2amine series were be docked into the non-nucleoside inhibitor binding pocket (NNIBP) of HIV-1 RT. As illustrated in Figure 1b, 1a and native ligand TMC 278 in Figure 1c and 2c, the 1-phenyl-1H-1,2,3-triazol4 -yl)methyl and 4-phenyl-thiazole moiety of compound $4 \mathbf{k}$ and $4 \mathrm{~h}$ of 4-(phenyl)-N,N-bis((1-phenyl-1H-1,2,3-triazol-4-yl)methyl)thiazol2 -amine series interacts through hydrophobic interactions into the hydrophobic binding pocket, surrounded by the aromatic portion of Tyr 181, Tyr 188, Phe227, Trp 229, Val 106, Pro 226, Pro 225, Pro 233 , Lbu 234, Pro95, Val 381and Ile 382. From the two dimensional Figure 1 ( $1 \mathrm{a}$ and $1 \mathrm{~b})$ and three dimensional view Figure $2(2 \mathrm{a}$ and $2 \mathrm{~b})$, it is observed that Lys 101 and Lys 102 is juxtaposed for better interaction with the 4-(phenyl)-N, N-bis((1-phenyl-1H-1,2,3-triazol-4-yl)methyl) thiazol-2-amine series.

The methoxy and chlorophenyl- thiazolyl nucleus moiety at of compounds $\mathbf{4 h}$ and $\mathbf{4 k}$ makes $\pi-\pi$ interaction into the hydrophobic binding pocket, surrounded by the aromatic side chains of portion of Trp229 and Tyr 181 residue. The $\mathrm{N}$-aryl substituted triazolyl ring of the compound $4 \mathbf{k}$ and $4 \mathbf{h}$ makes $\pi$ - cation interaction with into the hydrophobic binding pocket, surrounded by the aromatic side chains of portion of lys 103 residue. Triazolyl ring of compound $4 \mathrm{~h}$ form the hydrogen bond interactions with the backbone $\mathrm{N}-\mathrm{H}$ of Lys 101 residue. The decrease in activity of compounds $4 \mathrm{l}$ and $4 \mathrm{f}$ of 4 -(phenyl)-N,Nbis((1-phenyl-1H-1,2,3-triazol-4-yl)methyl)thiazol-2-amine series was due to lack of $\pi-\pi$ interaction of the methoxy and chlorophenylthiazolyl nucleus into the hydrophobic binding pocket, surrounded by the aromatic side chains of portion of Trp229 and Tyr 181 residue and nonexistence of $\pi$ - cation interaction with the hydrophobic binding pocket, surrounded by the aromatic side chains of portion of lys 103 residue (Figure 3 ), instead it is showing $\pi-\pi$ stacking of triazolyl ring with amino acid Trp 229 and Tyr181.

Docking score of compound $\mathbf{4 k}, \mathbf{4 h}, \mathbf{4 f}$ and $\mathbf{4 l}$ was found to be around $-11.126,-11.126,-8.189$ and -7.698 respectively, (Table 2) while of native ligand was found to be -13.413 which confirms that $4 \mathbf{k}$ and $4 \mathbf{h}$ compounds might have potent RT inhibition activity. Further, in silico binding studies suggested that inhibitors possessing $\pi-\pi$ interaction of the phenyl-thiazolyl nucleus into the hydrophobic binding pocket,

\begin{tabular}{|c|c|c|c|c|c|c|c|c|}
\hline Title & Entry ID & Entry Name & docking score & XP GScore & glide gscore & glide evdw & glide ecoul & glide energy \\
\hline $\mathbf{2 Z D 1}$ & 1 & glide-dock_XP_52 & -13.413 & -13.457 & -13.457 & -101.873 & -1.34345 & -50.4541 \\
\hline $\mathbf{4 k}$ & 2 & 15.1 & -11.1263 & -11.1263 & -11.1263 & -54.7834 & -2.59395 & -57.3774 \\
\hline $\mathbf{4 h}$ & 3 & 10.1 & -11.1258 & -11.1258 & -11.1258 & -60.5585 & -3.24128 & -63.7998 \\
\hline $\mathbf{4 j}$ & 4 & 12.1 & -10.9713 & -10.9713 & -10.9713 & -61.5987 & -3.11247 & -64.7112 \\
\hline $\mathbf{4 d}$ & 5 & 5.1 & -10.7285 & -10.7285 & -10.7285 & -62.5732 & -5.22558 & -67.7988 \\
\hline $\mathbf{4 b}$ & 6 & 2.1 & -10.7091 & -10.7091 & -10.7091 & -62.1431 & -2.66609 & -64.8092 \\
\hline $\mathbf{4 c}$ & 7 & 3.1 & -10.5749 & -10.5749 & -10.5749 & -69.3255 & -4.80454 & -74.13 \\
\hline $\mathbf{4 0}$ & 8 & 20.1 & -10.5425 & -10.5425 & -10.5425 & -59.2958 & -3.03547 & -62.3313 \\
\hline $\mathbf{4 a}$ & 9 & 1.1 & -10.4981 & -10.4981 & -10.4981 & -57.6595 & -2.86637 & -60.5259 \\
\hline $\mathbf{4 m}$ & 10 & 18.1 & -10.2797 & -10.2797 & -10.2797 & -58.6892 & -2.58555 & -61.2747 \\
\hline $\mathbf{4 e}$ & 11 & 6.1 & -10.01 & -10.01 & -10.01 & -64.0245 & -3.02913 & -67.0536 \\
\hline $\mathbf{4 i}$ & 12 & 11.1 & -9.90918 & -9.90918 & -9.90918 & -46.3341 & -3.84074 & -50.1749 \\
\hline $\mathbf{4 g}$ & 13 & 8.1 & -9.66711 & -9.66711 & -9.66711 & -60.6078 & -2.21859 & -62.8264 \\
\hline $\mathbf{4 n}$ & 14 & 17.1 & -9.04021 & -9.04021 & -9.04021 & -68.7023 & -5.5481 & -74.2504 \\
\hline $\mathbf{4 f}$ & 15 & 7.1 & -8.1886 & -8.1886 & -8.1886 & -69.3229 & -5.25723 & -74.5802 \\
\hline $\mathbf{4}$ & 16 & 16.1 & -7.698 & -7.698 & -7.698 & -67.4032 & -2.89727 & -70.3004 \\
\hline
\end{tabular}

Table 2: Molecular docking scores of the newly synthesized compounds due binding interaction with active site of HIV-1 reverse transcriptase (RT) in complex with TMC278. 


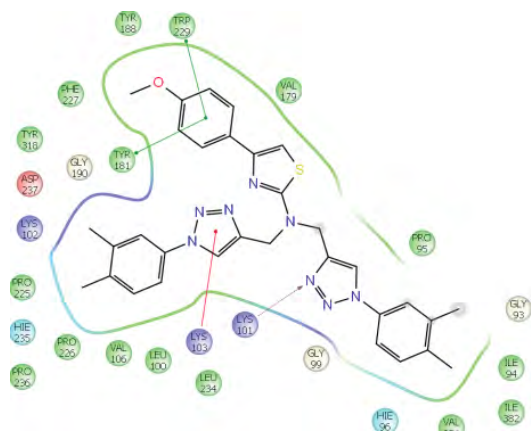

la

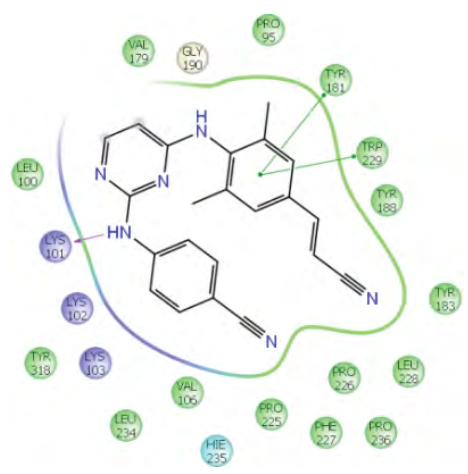

$1 \mathrm{~b}$

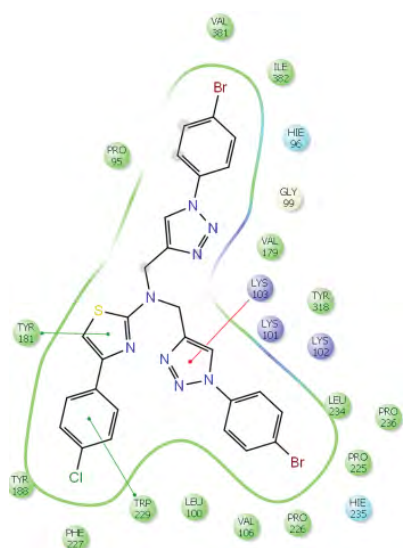

$1 \mathrm{c}$

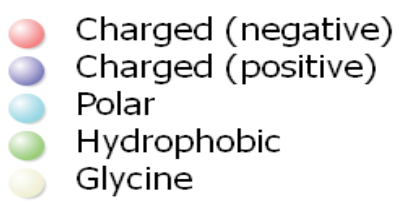

$\begin{array}{ll} & \text { Metal } \\ \mathrm{H}_{2} O & \text { Water } \\ & \text { Hydration site } \\ \otimes & \text { Displaced hydration site } \\ \bullet & \Pi-\Pi \text { stacking }\end{array}$

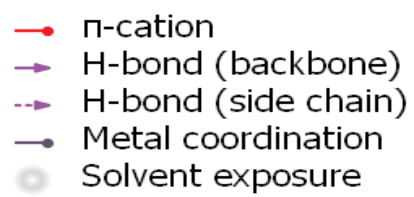

Figure 1: Two-dimensional view of the binding interaction of the most active compounds, 4h (1a), 4k (1b) with active site of HIV-1 reverse transcriptase (RT) in complex with TMC278 and native ligand TMC 278 (2c) with HIV-1 reverse transcriptase (RT). Abbreviations: VAL, valine; LEU, leucine; GLY, glycine; ASP, aspartate; SER, serine; ALA, alanine; LYS, Iysine; ILE, isoleucine; HIE, histidine epsilon H; MET, methionine; THR, threonine.

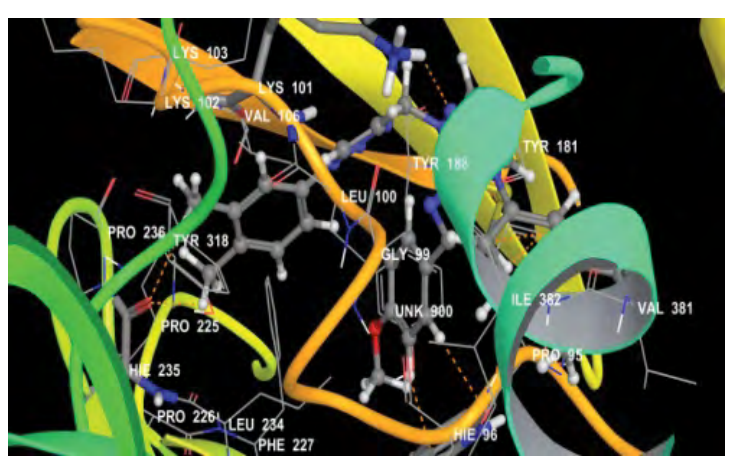

a

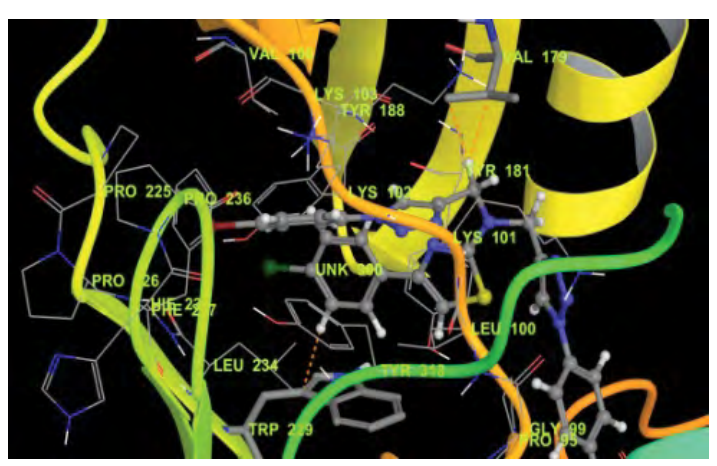

b

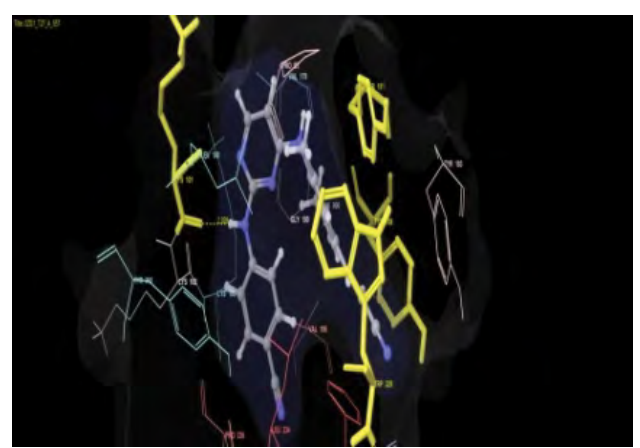

$\mathrm{C}$

Figure 2: Three dimensional view of the binding interaction of the most active compounds, $4 \mathrm{~h}(2 \mathrm{a}), 4 \mathrm{k}(2 \mathrm{~b})$ with active site of HIV-1 reverse transcriptase (RT) in complex with TMC278 and native ligand TMC278 (3c) with HIV-1 reverse transcriptase (RT). 


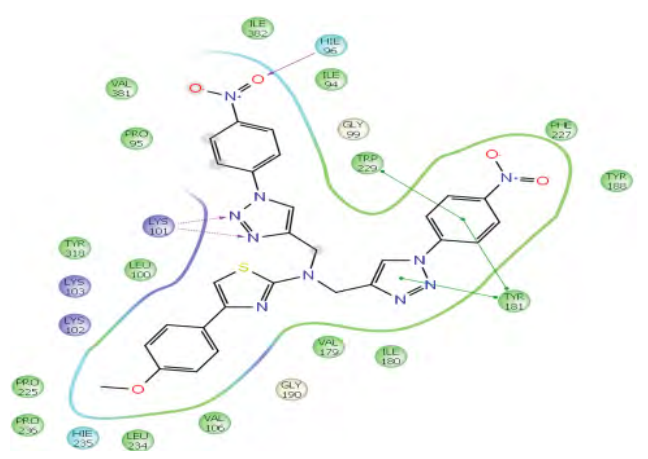

a

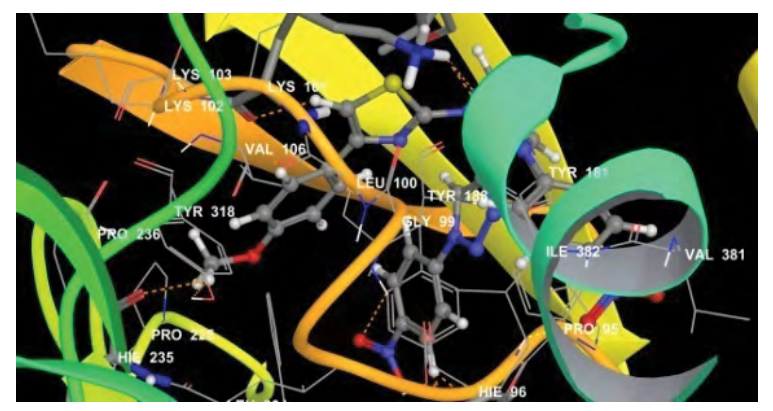

$\mathrm{c}$

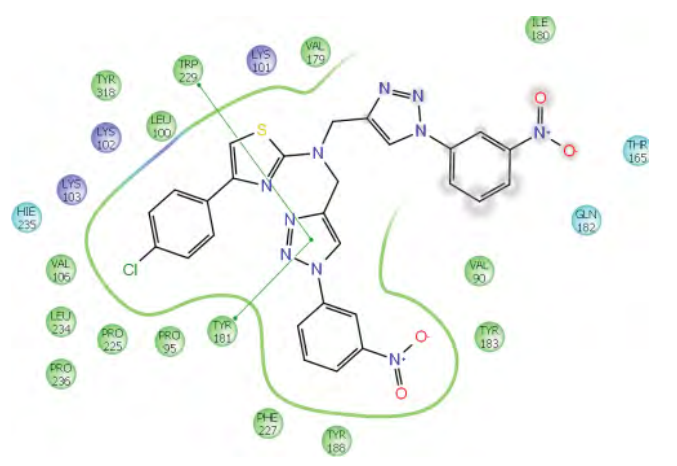

b

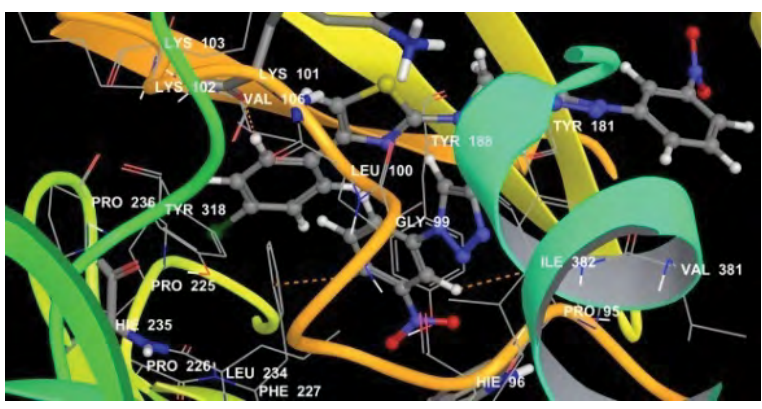

d

Figure 3: Two $(3 a, 3 b)$ and three-dimensional (3c and $3 d)$ view for decrease in activity of compound $4 \mathrm{I}$ and $4 \mathrm{f}$ respectively.

\begin{tabular}{|c|c|c|c|c|c|c|c|c|}
\hline \multirow[t]{3}{*}{ Compound } & \multirow[t]{3}{*}{$\mathbf{R}$} & \multicolumn{6}{|c|}{ Anti-HIV-1 activity } & \multirow{3}{*}{$\begin{array}{c}\% \text { Inhibition (HIV-RT kit assay) } \\
(100 \mu \mathrm{g} / \mathrm{ml})\end{array}$} \\
\hline & & \multicolumn{2}{|c|}{$\mathrm{EC}_{50}{ }^{\mathrm{b}}(\mu \mathrm{g} / \mathrm{ml})$} & \multicolumn{2}{|c|}{$\mathrm{CC}_{50}{ }^{\mathrm{c}}(\mu \mathrm{g} / \mathrm{ml})$} & \multicolumn{2}{|c|}{$\mathrm{SI}^{\mathrm{d}}$} & \\
\hline & & HIV-1IIIB & ADA5 & HIV-1 IIIB & ADA5 & HIV-1 IIIB & ADA5 & \\
\hline $4 k$ & $4-\mathrm{Br}$ & 0.65 & 1.02 & 40.3 & 41.8 & 62 & 40.98 & 91.45 \\
\hline $4 h$ & $3,4-\mathrm{CH}_{3}$ & 0.93 & 0.25 & 38.9 & 45.2 & 41.82 & 180.8 & 90.40 \\
\hline 40 & $3,4-\mathrm{CH}_{3}$ & 0.7 & 0.29 & 37.78 & 46.86 & 53.97 & 161.58 & 86.67 \\
\hline $4 f$ & $4-\mathrm{NO}_{2}$ & 1.32 & 1.22 & 50.78 & 48.3 & 38.46 & 39.53 & 66.88 \\
\hline 41 & $3-\mathrm{NO}_{2}$ & 0.98 & 0.81 & 3.42 & 5.5 & 3.48 & 6.79 & 64.71 \\
\hline Nevirapine & & 0.05 & 0.05 & 76.12 & 76.15 & 1522.51 & 1522.51 & 99.15 \\
\hline
\end{tabular}

aData represent the mean of two and three independent assays for $\mathrm{EC}_{50}$ and $\mathrm{CC}_{50}$, respectively; ${ }^{\text {b }} \mathrm{EC}{ }_{50}$ is the $50 \%$ effective concentration required to reduce $\mathrm{HIV}-1$ induced cytopathic effect of HIV-1 IIIB and HIV-1 ADA5; ' ${ }^{T}$ e $\mathrm{CC}_{50}$ is the $50 \%$ cytotoxic concentration for HIV-1 IIIB and HIV-1 ADA5; ${ }^{d}$ Selectivity index ratio CC ${ }_{50} / \mathrm{EC}_{50}$

Table 3: Anti-HIV-1 activity, cytotoxicity and selectivity index in HIV-1IIB, ADS5 and HIV-1 RT kit assay for compounds.

surrounded by the aromatic side chains of portion of Trp 229 and Tyr 181 residue and $\pi$-cation interaction with the aromatic side chains of portion of lys 103 residue improves the inhibitor selectivity for RT and thus helps in further drug design attempts to obtain potent 1,2,3, triazolyl- phenylthiazole derivatives.

\section{In vitro anti-HIV}

According to the docking study of synthesized compounds, some of it showed the high inhibition activity and some with low activity. From the above conclusion, we studied in vitro anti-HIV assay for particular compounds to verify their activity. The HIV-RT inhibition assay was performed by using an RT assay kit (Roche), and the procedure for assaying RT inhibition was performed as described in the kit protocol (Roche Kit) [34]. The compounds presented in this study namely 24-(phenyl)-N,N-bis((1-phenyl-1H-1,2,3-triazol-4-yl)methyl)thiazol2-amine derivatives $(\mathbf{4 k}, \mathbf{4 h}, \mathbf{4 o}, \mathbf{4 f}, \mathbf{4 l})$ were evaluated for anti-HIV-1 activity by using enzymatic (RT) and cell based assays. The HIV-1 RT inhibition activity range for these compounds showed from $64-92 \%$ inhibition at $100 \mu \mathrm{g} / \mathrm{ml}$ concentrations. The compounds $4 \mathbf{k}$ and $4 \mathbf{h}$ showed highest inhibitory activity both in docking as well cell based study $(91.45 \%, 90.0 \%)$ respectively, were $\mathbf{4 o}, \mathbf{4 f}$ and $\mathbf{4 1}$ shows low activity $(86.67,66.88 \%$ and $64.71 \%)$ respectively, whereas the control NNRTI marketed drug nevirapine showed $99.15 \%$ inhibition at 100 $\mu \mathrm{g} / \mathrm{ml}$ concentration. The enzyme assay results demonstrated that the compound $4 \mathbf{k}$ and $4 \mathbf{h}$ were more potent than remaining derivatives comparing against reverse transcriptase enzyme. Subsequently, the inhibitory activity of HIV-1 viral replication was also assessed by cellbased assay. The results are summarized in Table 3 along with standard nevirapine as reference drug. In the cell based assay, the compounds $4 \mathbf{k}$ and $4 \mathbf{h}$ were the most potent inhibitors of HIV-1 replication against HIV-1 IIIB $\left(\mathrm{EC}_{50}=0.65\right.$ and $0.93 \mu \mathrm{g} / \mathrm{ml}$ respectively; the selectivity index $(\mathrm{SI})=62.00$ and 41.82 respectively; $\mathrm{CC}_{50}$ with $\mathrm{HIV}-1 \mathrm{IIIB}=40.3$ and $38.9 \mu \mathrm{g} / \mathrm{ml}$ respectively) and HIV-1 ADA5 $\left(\mathrm{EC}_{50}=1.02\right.$ and $0.25 \mu \mathrm{g} /$ $\mathrm{ml}$; the selectivity index $(\mathrm{SI})=40.98$ and 180.8 respectively; $\mathrm{CC}_{50}=41.08$; 
Citation: Kasralikar HM, Jadhavar SC, Bhansali SG, Patwari SB, Bhusare SR (2017) Design, Synthesis and Docking Studies of Novel 1, 2, 3-Triazolyl Phenylthiazole Analogs as Potent Anti-HIV-1 NNRT Inhibitors. Med Chem (Los Angeles) 7: 268-275. doi: 10.4172/2161-0444.1000467

$45.2 \mu \mathrm{g} / \mathrm{ml}$ respectively). Some other compounds, $\mathbf{4 0}, \mathbf{4 f}$ and $\mathbf{4 1}$ showed low anti-HIV-1 potency $\left(\mathrm{EC}_{50}=0.7,1.32,0.98\right.$ and $0.29,1.22,0.81 \mu \mathrm{g} /$ $\mathrm{ml}$ ) against HIV-1 IIIB and HIV-1 ADA5 strains, respectively.

\section{Conclusion}

A series of new 1,2,3-triazolyl-phenyl thiazole hybrids bearing different aryl triazolyl/phenylthiozole moieties were synthesized and evaluated as potent inhibitors of human immunodeficiency virus type1 (HIV-1). Based upon the preliminary molecular docking studies of these new 1,2,3-triazolyl-phenyl thiazole hybrids, some structural requirements for high potency against HIV-1 were rationalized. In the series of 1,2,3-triazolyl-phenyl thiazole, compound $\mathbf{4 k}$ and $\mathbf{4 h}$ identified as potent inhibitor against the strains HIV-1 IIIB and HIV-1 ADA5. The decrease in activity of compound $4 \mathbf{f}$ and $\mathbf{4 1} 1,2,3$, triazolylphenylthiazole was due to lack of $\pi$-cation interaction with lys103. This study suggested that inhibitors' possessing $\pi$-cation interaction with lys 103 and $\pi-\pi$ interaction with the aromatic side chains of Trp 229 and Tyr 181 improves the inhibitor selectivity for RT.

\section{Supporting Information}

It includes docking score table and full characterization of synthesized compounds.

\section{Acknowledgments}

We acknowledge Dr. PL More, Dnyanopasak College, Parbhani for providing necessary facilities and Vishnu Chemical Labrotary, Hyderabad for providing spectral data is highly appreciated and also Poona College of Pharmacy, Bharati Vidyapeeth Deemed University, Pune for biological evolution.

\section{References}

1. Ulusoy N, Kiraz M, Kucukbasmaci, (2002) New 6-(4-Bromophenyl)imidazo[2,1-b] thiazole Derivatives: Synthesis and Antimicrobial Activity. Monatshefte Fur Chemie 133: 1305-1315.

2. Kaplancik ZA, Zitouni GT, Revial G, Guven K (2004) Synthesis and study of antibacterial and antifungal activities of novel 2-[(benzoxazole/benzimidazole2-yl)sulfanyl] acetyl- amino]thiazoles. Archives of Pharmacal Research 27 : 1081-1085.

3. Al-Saddi MS, Faidallah HM, Rostom SAF (2008) Synthesis and biological evaluation of some 2,4,5-trisubstituted thiazole derivatives as potential antimicrobial and anticancer agents. Archives of Pharmacal Chemical and Life Science 341: 424-434

4. Karpov KA, Nazarenko AV, Pekarevskii BV, Potekhin VM (2001) Biocidal and Anti-corrosive effect of aminothiazole derivatives used as additives to jet fuels. Russian Journal of Applied Chemistry 74: 998-1001.

5. Baselt T, Rehse K (2008) New 2-amino-thiazole-4-acetamides with antiplatele activity. Archiv der Pharmazie 341: 645-654.

6. Karade HN, Acharya BN, Manisha S, Kaushik MP (2008) Design, synthesis, and antimalarial evaluation ofthiazole-derived amino acids. Medicinal Chemistry Research 17: 19-29.

7. Kalgutkar AS, Driscoll J, Zhao SX, Walker GS, Shepard RM, et al. (2007) A rational chemical intervention strategy to Circumvent bioactivation liabilities associated with a nonpeptidyl thrombopoietin receptor agonist containing a 2-amino-4-arylthiazole motif. Chemical Research in Toxicology. 20: 954-965.

8. Antipas AS, Blumberg LC, Brissette WH, Brown MF, Casavant JM, et al. (2010) Structure- activity relationships and hepatic safety risks of thiazole agonists of the thrombopoietin receptor. Bioorganic Medicinal Chemistry Letter 20: 40694072.

9. Nettekoven M, Guba W, Neidhart W, Mattei P, Pflieger P, et al. (2006) Aminothiazole derivatives as neuropeptide $Y 5$ receptor ligands: finding the balance between affinity and physicochemical properties. Chem Med Chem 1: $45-48$

10. van Tilburg EW, van der Klein PAM, de Groote $M$, Beukers MW, ljzerman AP (2001) Substituted 4-phenyl-2-(phenylcarboxamido)-1,3-thiazole derivatives as antagonists for the adenosine A1 receptor. Bioorganic Medicinal Chemistry Letter 11: 2017- 2019.

11. van Muijlwijk Koezen JE, Timmerman H, Vollinga RC, Frijtag von Drabbe
Keunzel J, de Groote M, et al. (2001) Thiazole and thiadiazole analogues as a novel class of adenosine receptor antagonists. Journal of Medicinal Chemistry. 44: 749-762.

12. Kim KS, Kimball SB, Misra RN, Rawlins DB, Hunt JT, et al. (2002) Discovery of aminothiazole inhibitors of cyclin-dependent kinase 2: synthesis, X-ray crystallographic analysis, and biological activities, Journal of Medicinal Chemistry. 45: 3905-3927.

13. Zhang WT, Ruan JL, Wu PF, Jiang FC, Zhang LN, et al. (2009) Design, synthesis, and cytoprotective effect of 2-aminothiazole analogues as potent poly(ADP-ribose) polymerase-1 inhibitors. Journal of Medicinal Chemistry 52: 718-725.

14. Wilson KJ, Illig CR, Subasinghe N, Hoffman JB, Rudolph MJ, et al. (2001) Synthesis of thiophene-2-carboxamidines containing 2-aminothiazoles and their biological evaluation as urokinase inhibitors. Bioorganic Medicinal Chemistry Letter 11: 915-918.

15. Bennett JP, Piercey MF (1999) Pramipexole-a new dopamine agonist for the treatment of Parkinson's disease. Journal of Neurological Science 163: 25-31.

16. Zhang AFLi, Ding C, Yao Q, Knapp BI, Bidlack JM, et al. (2007) Synthesis and pharmacological evaluation of 6,7-indolo/thiazolo-morphinans--further SAR of levorphanol. Journal of Medicinal Chemistry. 50: 2747-51.

17. Zhang A, Xiong W, Hilbert JE, DeVita EK, Bidlack JM, et al. (2004) Synthesis and pharmacological evaluation of 6,7-indolo/thiazolo-morphinans further SAR of levorphanol. Journal of Medicinal Chemistry 50: 2747-2751.

18. Fan WQ, Katritzky AR, Katritzky AR, Rees CW, Scriven CWV (1999) Comprehensive Heterocyclic Chemistry II, 4: 1.

19. Alvarez R, Velazquez S, San-Felix A, Aquaro S, Clercq ED, et al. (1994) 1,2,3-Triazole-[2,5-Bis-O-(tert-butyldimethylsilyl)- $\beta$-D- ribofuranosyl]-3 \& apos; -spiro-5'-(4' -amino-1',2 ' -oxathiole 2 ', 2' - dioxide) (TSAO) Analogs: Synthesis and Anti-HIV-1 Activity. Journal of Medicinal Chemistry 37: 4185-4194.

20. Chakole RD, Amnerkar ND, Khedekar PB, Bhusari KP (2005) Synthesis and substituted benzothiazole derivatives of thioquinazoline as anti-convulsant agents. Indian Journal of Heterocyclic Chemistry 15: 27-30.

21. Buckle DR, Outred DJ, Rockell CJM, Smith H, Spicer BA (1983) Studies on $\mathrm{v}$ - triazoles. Antiallergic 9-oxo-1H, $9 \mathrm{H}$-benzopyrano[2,3-d]-v-triazoles. Journal of Medicinal Chemistry 26: 251-254

22. Siddiqui N, Alam M, Siddiqui AA (2004) Synthesis and Analgesic Activity of Some 2- $\{4-($ Alkyl thioureido)phenyl sulphonamido]-6-substituted benzothiazoles. Asian Journal of Chemistry 16: 1005-1008.

23. Gurupadayya BM, Gopal M, Padmashali B, Vaidya VP (2005) Synthesis and Bological activities of Fuorobenzothiazoles. Indian Journal of Heterocyclic Chemistry 15: 169-172.

24. Costa MS, Boechat N, Rangel EA, de Silva FC, de Souza AMT, et al. (2000) Synthesis, Tuberculosis inhibitory activity, and SAR study of N-substitutedphenyl-1,2,3-triazole Derivatives, Bioorganic Medicinal Chemistry 14: 8644 8653.

25. Du Z, Wei X, Zhang W, Zhang Y, Xue Q (2013) Catalyst-Free and Highly Selective $\mathrm{N}$-Diallylation of Anilines in Aqueous Phase. Journal of Chemistry 5-9.

26. Hu M, Li J, Yao SQ (2008) In situ "click" assembly of small molecule matrix Metalloprotease inhibitors containing zinc-chelating groups. Organic Letters. 10: 5529-5531.

27. Kolb HC, Finn MG, Sharpless KB (2001) Click Chemistry: Diverse Chemical Function from a Few Good Reactions. Angewandte Chemie International Edition 40: 2004-2021.

28. Glide (2009) Version 5.5, Schrödinger LLC, New York, NY, USA.

29. Das K, Bauman JD, Clark ADJ, Frenkel YV, Lewi PJ, et al. (2008) Proceeding of National Academy of Science, USA 105: 1467.

30. LigPrep (2009) Version 2.3, Schrödinger LLC, New York, NY, USA.

31. Maestro (2009) Version 9.0, Schrödinger LLC, New York, NY, USA

32. Friesner RA, Banks JL, Murphy RB, Halgren TA, Klicic JJ, et al. (2004) Glide: a new approach for rapid, accurate docking and scoring. Method and assessment of docking accuracy. Journal of Medicinal Chemistry. 47: 1739-1749. 
Citation: Kasralikar HM, Jadhavar SC, Bhansali SG, Patwari SB, Bhusare SR (2017) Design, Synthesis and Docking Studies of Novel 1, 2, 3-Triazolyl Phenylthiazole Analogs as Potent Anti-HIV-1 NNRT Inhibitors. Med Chem (Los Angeles) 7: 268-275. doi: 10.4172/2161-0444.1000467

33. Halgren TA, Murphy RB, Friesner RA, Beard HS, Frye LL, et al. (2004) Glide: a new approach for rapid, accurate docking and scoring. 2. Enrichment factors in database screening, Journal of Medicinal Chemistry 47: 1750-1759.
34. Reverse Transcriptase Assay, Colorimetric Kit, Roche Diagnostics GmbH Roche Applied Science, Sandhofer Strasses 116, D-68305 Mannheim, Germany. 